\title{
SERVICE QUALITY AT TECHNICAL AND VOCATIONAL EDUCATION AND TRAINING COLLEGES: PERCEPTION ACCORDING TO DEMOGRAPHIC FACTORS
}

\author{
Mason, R.B. ${ }^{1}$, Mbambo, S.N. ${ }^{2}$ \& Pillay, M.A. ${ }^{3}$ \\ ${ }^{1,2,3}$ Department of Marketing and Retail Management, \\ Durban University of Technology, Durban, South Africa \\ Correspondence author email: rogerm@dut.ac.za
}

Received August 22 $2^{\text {nd }}, 2017$; Accepted February $8^{\text {th }}, 2018$

\begin{abstract}
TVET colleges are regarded as second-class educational institutions in South Africa. As a result, their enrolment targets are not being met, which is a problem for the development and growth of this educational sector. The objective of this paper is to identify whether students' satisfaction with the service quality provided by TVET colleges differ according to selected demographic factors, and thus help to understand specific reasons for not meeting their enrolment targets. A survey of 301 respondents from six colleges, using a SERVQUAL questionnaire, comprised the methodology. The results showed little difference in satisfaction with service quality according to the demographic factors tested - all respondents were more or less equally dissatisfied with the service quality of their TVET colleges. Therefore, looking for reasons for the poor enrolment levels amongst the different demographic characteristics of the students is pointless. The poor service quality perceived is probably due to inadequate systems, or inadequate management or staff training, rather than failure to meet specific needs of students from different demographic types. Recommendations are provided for overcoming the poor service, and for further research.
\end{abstract}

Keywords: Service quality dimensions, stakeholders' perceptions, demographic influence DOI: https://10.30880/jtet.2018.10.01.002 


\section{INTRODUCTION}

In 2007, the South African Department of Education (DoE) indicated that it wanted enrolments at TVET colleges to increase to one million by 2014/15 (South Africa. Department of Education 2007). To help facilitate this growth, the National Certificate (Vocational) (NCv) curriculum was introduced with courses attractive to ambitious students (South Africa. Department of Education, 2007). In 2008, 400000 students enrolled at TVET colleges (South Africa. Department of Education 2008), but this decreased to 220000 by 2010. This decrease in enrolment was influenced by the phasing out of the Nated curriculum in favour of the new National Certificate (Vocational) (NCv) (Cosser, 2011). In 2016 TVET colleges were reported to have more than 700000 students (TVET Colleges South Africa, 2016), but in late 2016 were reported to have only 580719 enrolments, down from the 614 358 enrolments in 2015 (van Rensburg, 2016). One of the challenges to understanding the under-achievement of the million-student goal is the poor public perception of TVET college programmes (Department of Education, 2008), despite the fact that four out of five young people are interested in receiving training (Myeza, Mason \& Peddermors, 2010). This sector is regarded and perceived by students as a last option at which to pursue training. Ceza (2008) believes this is because of their practical nature, suited to those who are not mentally gifted but who are practically gifted.

In 2001, 152 technical colleges, with 200 delivery sites across South Africa, merged to form 50 TVET colleges. According to the Department of Education, this merger intended to improve and uplift the standard of education to meet the challenges of the labour market and to enhance co-operative governance, management, leadership and education (Akoojee \& McGrath, 2008). Unfortunately, little research on service quality at TVET colleges has since been done. Knowledge of service quality assessments made by students could assist to understand this so-called "poor public perception" and would enable managers to direct resources into important areas that influence perceptions. In a recent study, Pillay, Mbambo, and Mason (2017) found that the expectations of TVET students consistently exceeded their perceptions of the service quality they received, thus leading to dissatisfaction with their TVET college.

What was not clear from this study was whether this dissatisfaction differed according to demographic factors such as age, gender, etc. Therefore, this paper aims to examine whether student levels of satisfaction, or dissatisfaction, with the service quality provided by TVET colleges differ according to selected demographic factors that define different categories of students at TVET colleges.

\subsection{Problem statement}

TVET colleges are clearly struggling with enrolments and student intake (Akoojee \& McGrath, 2008). The majority of students registered with the TVET sector are mostly referred by universities to TVET colleges. Students do not perceive and choose TVET colleges as an institution of priority after completion of high school. Akoojee points out those colleges have no influence over attracting student intake (Akoojee, 2009). The phasing out of N4 to N6 certificates (old Nated curriculum) in favour of the new National Certificate (Vocational) - (new NCv) resulted in a decrease in enrolment intake from 400000 to 220000 (Cosser, 2011). Since then, enrolments have not come anywhere near the goal of a million TVET enrolments. In addition to funding problems (van Rensburg, 2016), this might indicate an overall negative perception of TVET colleges, as the preferred choice of further education 
and training. TVET's future, as a preferred institution, is uncertain and, unless TVET colleges can identify the reasons, it will be difficult to meet their enrolment goals. Therefore, the research problem faced involves TVET colleges not understanding students' attitudes towards TVET colleges.

\subsection{Research objectives and hypotheses}

The main purpose of this study was to identify whether students' levels of satisfaction with the service quality provided by TVET Colleges differ according to selected demographic factors, as per the following hypotheses:

H 1: there is no relationship between gender \& satisfaction with service quality

H 2: there is no relationship between ethnicity \& satisfaction with service quality

H 3: there is no relationship between age \& satisfaction with service quality

$H$ 4: there is no relationship between qualification before registration \& satisfaction with service quality

H 5: there is no relationship between method of payment for studies \& satisfaction with service quality

H 6: there is no relationship between the old, Nated level (year) registered for \& satisfaction with service quality

$H$ 7: there is no relationship between the new NCv level (year) registered for \& satisfaction with service quality

Though limited to only one province in South Africa, the findings are felt to be important as this province has the second largest population, and a representative number of the province's TVET colleges were included in the sample. The findings of this paper will therefore be of relevance to all TVET colleges in South Africa, and probably also to further education colleges in other developed and developing countries. The findings should help management to improve service quality so as to meet the expectations of all potential enrolees, and thus also improve student perceptions. This should contribute to an increased intake of students to TVET colleges.

\section{LITERATURE REVIEW}

As mentioned above, TVET colleges are tasked with significant growth. However, with only about 10000 academic staff, the current enrolments (660 000) mean a staff: student ratio that is antithetic to quality service (Mmako \& Schultz, 2016). Furthermore, in 2009, the old NATED courses were reintroduced and TVETs now have to cope with both the old NATED and new $\mathrm{NCv}$ courses, which also throws into question their ability to cope with an increasingly complex situation (Mmako \& Schultz, 2016). Unfortunately, very little research has been conducted into these issues and it thus appears as if little is being done to improve the situation at TVET colleges. It is therefore not unexpected that TVET colleges have developed a poor image among prospective students.

Education is a marketable service like any other service (Russell, 2005), and so marketing in the education sector is essential for student recruitment (Ivy, 2001; Maringe \& Foskett, 2002). Therefore, TVET colleges, who face the challenges of meeting enrolment targets, need to understand students' attitudes in order to develop effective marketing actions (Binsardi \& Ekwulugo, 2003). A positive perception regarding a college will help students to 
make an informed decision as to which institution to choose, namely, the college that they expect will satisfy their desired needs. Perceptions about an educational institution are influenced by an institutions' image, branding and reputation, quality of teaching, financial aid and scholarships, location of the institution, student support facilities, academic and administrations issues, admission requirements and Quality of College Life (QCL) (de Jager \& du Plooy, 2006; Ivy, 2001; Pillay, 2010; Russell, 2005; Yu \& Lee, 2008).

\subsection{Satisfaction with service quality}

Satisfaction is a customer's assessment of whether a service meets the customers' desires and expectations (Bruhn \& Georgie, 2006). An alternative definition is "the difference between customer expectations and customer perceptions" (Harris, 2003: 2). Expectations are what customers ideally want - what they wish for and expect from an excellent service provider, and what they think should happen in the next service encounter, while perceptions are the actual service levels they experience (Lotz, 2009). Customers perceive service quality in terms of multiple factors rather than in a one-dimensional way (Zeithaml, Bitner \& Gremler, 2006). The SERVQUAL model is a common method of assessing service quality, measuring the 'Gap' between the expectations and perceptions (Parasuraman, Zeithaml \& Berry, 1985). SERVQUAL measures service quality in terms of five dimensions, namely tangibles, reliability, responsiveness, assurance and empathy. In this study, the SERVQUAL questionnaire was used to measure the students' satisfaction with the level of service quality they receive from their TVET college, on a five point Likert scale from $1=$ Strongly disagree to $5=$ Strongly agree. The dependent variable, "service quality satisfaction" is thus a dummy variable calculated from the means of the students' "gap" scores (perceptions minus expectations).

\subsection{Student demographics}

Most research into the customer service levels of, and satisfaction with, educational institutions has used one or other variants of the SERVQUAL instrument. However, many have not differentiated between different demographic levels, merely measuring the service quality gaps (e.g. Athiyaman, 1997; Çerri, 2012; Hasan, Ilias, Rahman \& Razak, 2008; Nadiria, Kandampully \& Hussain, 2009; Tsinidou, Gerogiannis \& Fitsilis, 2010; Wael, 2015). Those that have investigated the effect of demographic factors on satisfaction with service quality (mostly using SERVQUAL) have focused mostly on gender and study level (either year of under grad, or under- versus post-grad), with, to a lesser degree, nationality (country or foreign versus local) and age. In our study, we also identified qualification held prior to registration and method of payment as factors that possibly could indicate difference in perceptions of service quality. Table 1 summarises the findings of studies that assessed satisfaction with service levels according to these demographic factors. 
Table 1. Literature on service quality satisfaction according to demographic factors

\begin{tabular}{|c|c|c|c|c|c|c|c|}
\hline $\begin{array}{l}\text { Demographic } \\
\text { Authors } \\
\end{array}$ & Country & Gender & Ethnicity & Age & $\begin{array}{l}\text { Payment } \\
\text { method }\end{array}$ & $\begin{array}{l}\text { New } \\
\text { NCv } \\
\text { level } \\
\end{array}$ & $\begin{array}{c}\text { Old } \\
\text { Nated } \\
\text { level } \\
\end{array}$ \\
\hline Tan \& Kek, 2004 & Singapore & $\begin{array}{c}\text { No } \\
\text { differences }\end{array}$ & $\begin{array}{l}\text { Nationality } \\
\text { influences } \\
\text { satisfaction }\end{array}$ & & & \multicolumn{2}{|c|}{$\begin{array}{l}\text { No significant } \\
\text { differences }\end{array}$} \\
\hline $\begin{array}{l}\text { Jusoh, Omain, } \\
\text { Majid, Som \& } \\
\text { Shamsuddin, } \\
2004\end{array}$ & Malaysia & $\begin{array}{c}\text { No } \\
\text { differences }\end{array}$ & $\begin{array}{l}\text { No differences } \\
\text { for race }\end{array}$ & & & \multicolumn{2}{|c|}{$\begin{array}{c}\text { Are significant } \\
\text { differences }\end{array}$} \\
\hline $\begin{array}{l}\text { Joseph, Yakhou } \\
\text { \& Stone, } 2005 .\end{array}$ & USA & $\begin{array}{l}\text { Significant } \\
\text { difference }\end{array}$ & & & & \multirow{3}{*}{\multicolumn{2}{|c|}{$\begin{array}{l}\text { Newer/lower } \\
\text { level students } \\
\text { more satisfied }\end{array}$}} \\
\hline $\begin{array}{l}\text { Zafiropoulos \& } \\
\text { Vrana, } 2008\end{array}$ & Greece & $\begin{array}{l}\text { Minor } \\
\text { effect }\end{array}$ & & & & & \\
\hline $\begin{array}{l}\text { Palli \& Mamilla. } \\
2012\end{array}$ & India & $\begin{array}{c}\text { Does } \\
\text { influence } \\
\text { satisfaction }\end{array}$ & & $\begin{array}{l}\text { No effect on } \\
\text { satisfaction }\end{array}$ & $\begin{array}{l}\text { No effect } \\
\text { on satis- } \\
\text { faction }\end{array}$ & & \\
\hline $\begin{array}{l}\text { Koni, Zainal \& } \\
\text { Ibrahim, } 2013\end{array}$ & Palestine & $\begin{array}{l}\text { Does not } \\
\text { influence } \\
\text { satisfaction }\end{array}$ & & $\begin{array}{l}\text { Small effect } \\
\text { on satis- } \\
\text { faction }\end{array}$ & & \multicolumn{2}{|c|}{$\begin{array}{l}\text { Small influence } \\
\text { on satisfaction }\end{array}$} \\
\hline $\begin{array}{l}\text { Wilkins \& } \\
\text { Balakrishnan } \\
2013\end{array}$ & $\begin{array}{l}\text { United } \\
\text { Arab } \\
\text { Emirates }\end{array}$ & $\begin{array}{l}\text { Does not } \\
\text { influence }\end{array}$ & $\begin{array}{c}\text { Nationality } \\
\text { differences but } \\
\text { not significant }\end{array}$ & & & \multicolumn{2}{|c|}{$\begin{array}{c}\text { Differences but } \\
\text { not significant }\end{array}$} \\
\hline $\begin{array}{l}\text { Min \& Khoon, } \\
2014\end{array}$ & Singapore & $\begin{array}{l}\text { Influences } \\
\text { satisfaction }\end{array}$ & $\begin{array}{l}\text { Nationality } \\
\text { influences } \\
\text { satisfaction }\end{array}$ & $\begin{array}{l}\text { Influence } \\
\text { satisfaction }\end{array}$ & & \multicolumn{2}{|c|}{$\begin{array}{c}\text { Influence } \\
\text { satisfaction }\end{array}$} \\
\hline
\end{tabular}

Table 1 shows that there has been little consistency in the findings regarding the influence of demographic factors on the satisfaction with service quality at educational institutions. For example, half the studies show gender as influencing customer satisfaction, while the other half show that there is no influence. This uncertainty therefore justifies the need for this study to identify what the situation at TVET colleges in South Africa is. Thus, based on the extant literature, the independent variables selected were the demographic variables of Age, Gender, Ethnicity, Qualification before registering at a TVET, How paying for studies, Old Nated year of study and New NCv year of study, all of which are categorical variables.

\section{METHODOLOGY}

A cross-sectional, descriptive survey approach was used to identify if service quality in the current service offering at TVET colleges differs according to various demographic characteristics

\subsection{Sample}

Firstly, the KZN province was selected purposively due to this province having the second largest population in South Africa, accounting for a third of South Africa's population and $60 \%$ of its economic activity (Corbishley \& Mason, 2011). Furthermore, it has a large number of TVET colleges in both rural and urban areas, offering both new $(\mathrm{NCV})$ and old (Nated) curricula, and which provide a variety of types of respondents in terms of demographics. Secondly, all TVET colleges in KZN were included in the study. Thus, a 
census was attempted, although three colleges refused to participate. To select the number of respondents per college and the number for new and old curricula, quota sampling was used in proportion to the actual college population. Finally, convenience sampling was used to select the actual respondents, according to the quotas per college. Thus, the final sample was determined by who was accessible and available on the day of data collection and is illustrated Table 2. College names are anonymous at the request of the colleges.

Table 2. Sample structure

\begin{tabular}{lccc} 
TVET College & Sample & NCv & Nated \\
\hline College $A$ & 50 & 30 & 20 \\
College $B$ & 50 & 25 & 25 \\
College $C$ & 55 & 25 & 30 \\
College $D$ & 52 & 30 & 22 \\
College $E$ & 46 & 25 & 21 \\
College $F$ & 48 & 25 & 23 \\
Colleges $G$, H and I & Non-response & Non-response & Non-response \\
Six Colleges participated & $\mathbf{3 0 1}$ & $\mathbf{1 6 0}$ & $\mathbf{1 4 1}$ \\
\hline$\quad$ NCv = New Curricula: National Certificate (Vocational) - Levels 2 - 4.
\end{tabular}

\subsection{Instrument and procedure}

A questionnaire was administered to students on all campuses of the TVET colleges. The questionnaire comprised 7 demographic questions and 22 SERVQUAL questions to measure the students' expectations and perceptions of service quality at their TVET College. The SERVQUAL instrument is a validated instrument due to its many years of use in quality settings, including at educational institutions. The SERVQUAL component consists of a standardized questionnaire that includes two statements for each of the 22 items representing the five service dimensions. An "expectations" section is used to measure the expectations of students concerning a service, while a "perceptions" section is used to measure their assessments of that service (Perez, Abad, Carrillo \& Fernandez, 2007). Four of the 22 statements are used to measure tangibles, five for reliability, four for responsiveness, four for assurance and five for empathy. Statements in both sections use a five-point Likert scale anchored by "Strongly Agree" (5) to "Strongly Disagree" (1) (Curry \& Sinclair, 2002).

According to Leedy and Ormrod (2005), reliability can be seen as the consistency of performance of the measuring instrument. This means that, apart from delivering accurate results, the measuring instrument must deliver similar results consistently. The instrument's reliability has been confirmed in many previous studies. In addition, since our questionnaire was adapted for this study, we felt it necessary to assess its reliability. Cronbach's alpha was used, with a reliability coefficient of 0.70 or higher being considered as "acceptable" (Introduction to SAS, 2007).

Table 3. Reliability of SERVQUAL measures

\begin{tabular}{lll}
\hline Tangibles & .664 & .588 \\
Reliability & .834 & .808 \\
Responsiveness & .783 & .775 \\
Assurance & .774 & .722 \\
Empathy & .848 & .800 \\
Overall & .936 & .914 \\
\hline
\end{tabular}


As shown in Table 3, the overall reliability scores are high (0.936 for Expectations and 0.914 for Perceptions). This indicates a high degree of acceptable, consistent scoring. All of the dimensions have acceptable individual reliability values, except for Tangibles, and even that is in the vicinity of 0.6 . Overall reliability is thus considered acceptable.

\subsection{Data Analysis}

The collected data was analysed with the Statistical Package for Social Sciences (SPSS) version 20.0 for Windows. A descriptive analysis of the demographic questions and of the expectations, perceptions and service quality gaps of students was done. To calculate the dependent variable (service quality satisfaction) mean scores for the Servqual gaps were calculated and compared against each of the demographic, independent variables. Since the dependent variable (service quality satisfaction) is numerical and the independent variables (demographics) are categorical, the appropriate testing procedure is partial Eta square, which reflects the effect of the independent variables (demographic factors) on the service quality satisfaction mean score (dependent variable). These were obtained using the univariate option in the General Linear Model (Draper, 2017). Based on these partial ETA scores and their associated significance scores, hypothesis testing was conducted.

\section{FINDINGS}

In this section, the profile of the sample is first presented, followed by the analysis of the comparison of the dependent variable against the independent variables. Based on this statistical analysis, the hypothesis testing is discussed.

\subsection{Demographic profile of respondents}

Table 4 reflects the demographic profile of the 301 respondents, split by ethnicity, age, gender, qualification before entering college, the manner in which tuition fees are paid, and the programme and year level presently registered for.

Table 4. Biographical data of respondents

\begin{tabular}{lccc}
\hline Variables & Categories & n & \% \\
\hline Age & $18-19$ & 40 & 13.3 \\
& $20-21$ & 104 & 34.5 \\
& $22-23$ & 80 & 27.6 \\
Gender & $24+$ & 74 & 24.5 \\
& Male & 84 & 27.8 \\
Ethnicity* & Female & 217 & 72.2 \\
& African & 293 & 97.3 \\
Qualification & Asian & 6 & 2.0 \\
(before registering at TVET) & Mixed race & 2 & 0.7 \\
& Grade 9 & 7 & 2.3 \\
& Grade 10 & 10 & 3.3 \\
How paying for studies & Grade 11 & 46 & 15.3 \\
& Grade 12 & 226 & 75.1 \\
& Other & 12 & 4.0 \\
& NSFAS & 217 & 72.1 \\
& Bursary & 51 & 16.9 \\
& Parents & 25 & 8.3 \\
& Loan & 4 & 1.3 \\
& Other & 4 & 1.3 \\
\hline
\end{tabular}




\begin{tabular}{lccc}
\hline Variables & Categories & n & \% \\
\hline Nated level registered for & $\mathrm{N} 3$ & 75 & 53.2 \\
& $\mathrm{~N} 4$ & 13 & 9.0 \\
& $\mathrm{~N} 5$ & 20 & 14.3 \\
NCv level registered for & $\mathrm{N} 6$ & 33 & 23.3 \\
& Level 2 & 25 & 15.6 \\
& Level 3 & 41 & 25.9 \\
& Level 4 & 75 & 46.8 \\
\hline
\end{tabular}

* In South Africa, these categories are known as Black, Indian and Coloured, respectively

\subsection{The Overall SERVQUAL Scores}

The expectation, perception and gap scores per SERVQUAL dimension for the overall respondent group are summarised in Table 5.

Table 5. Overall expected (E), perceived (P), and gap scores ex SERVQUAL

\begin{tabular}{lccc}
\hline Dimensions & E & P & Gap \\
\hline Tangibles & 4.69 & 3.18 & -1.51 \\
Reliability & 4.36 & 2.77 & -1.59 \\
Responsiveness & 3.70 & 2.28 & -1.42 \\
Assurance & 4.68 & 3.11 & -1.57 \\
Empathy & 4.25 & 3.14 & -1.11 \\
\hline
\end{tabular}

These scores indicate that expectations considerably exceed perceptions for the overall sample, resulting in negative gap scores for all the SERVQUAL dimensions. This indicates that the respondents as an overall group are dissatisfied with the quality of service received from their TVET colleges.

\subsection{Satisfaction with service quality by demographic factors}

As mentioned previously, this study has the objective of identifying if levels of satisfaction differ according to demographic factors, or whether these negative satisfaction levels are all the same regardless of demographics. Thus, the expectations and perceptions were compared to produce gap scores according to the different demographic variables. These findings are presented in Table 6.

Table 6: Means, effect and significance by demographic factors

\begin{tabular}{|c|c|c|c|c|c|c|}
\hline Variables & Categories & Mean & $\begin{array}{c}\text { Partial Eta } \\
\text { squared }\end{array}$ & Effect & Sig & Significant \\
\hline Gender & $\begin{array}{c}\text { Male } \\
\text { Female }\end{array}$ & $\begin{array}{l}-0.463 \\
-0.381\end{array}$ & 0.004 & Small & 0.422 & No \\
\hline Ethnicity* & $\begin{array}{c}\text { African } \\
\text { Asian } \\
\text { Mixed race }\end{array}$ & $\begin{array}{l}-0.401 \\
-0.788 \\
-0.227\end{array}$ & 0.012 & Small & 0.361 & No \\
\hline Age & $\begin{array}{c}18-19 \\
20-21 \\
22-23 \\
24+\end{array}$ & $\begin{array}{l}-0.393 \\
-0.326 \\
-0.417 \\
-0.536\end{array}$ & 0.016 & Small & 0.454 & No \\
\hline $\begin{array}{l}\text { Qualification } \\
\text { (before } \\
\text { registering at } \\
\text { TVET) }\end{array}$ & $\begin{array}{l}\text { Grade } 9 \\
\text { Grade } 10 \\
\text { Grade } 11 \\
\text { Grade } 12\end{array}$ & $\begin{array}{r}0.032 \\
-0.355 \\
-0.201 \\
-0.495\end{array}$ & 0.050 & Medium & 0.079 & No \\
\hline
\end{tabular}




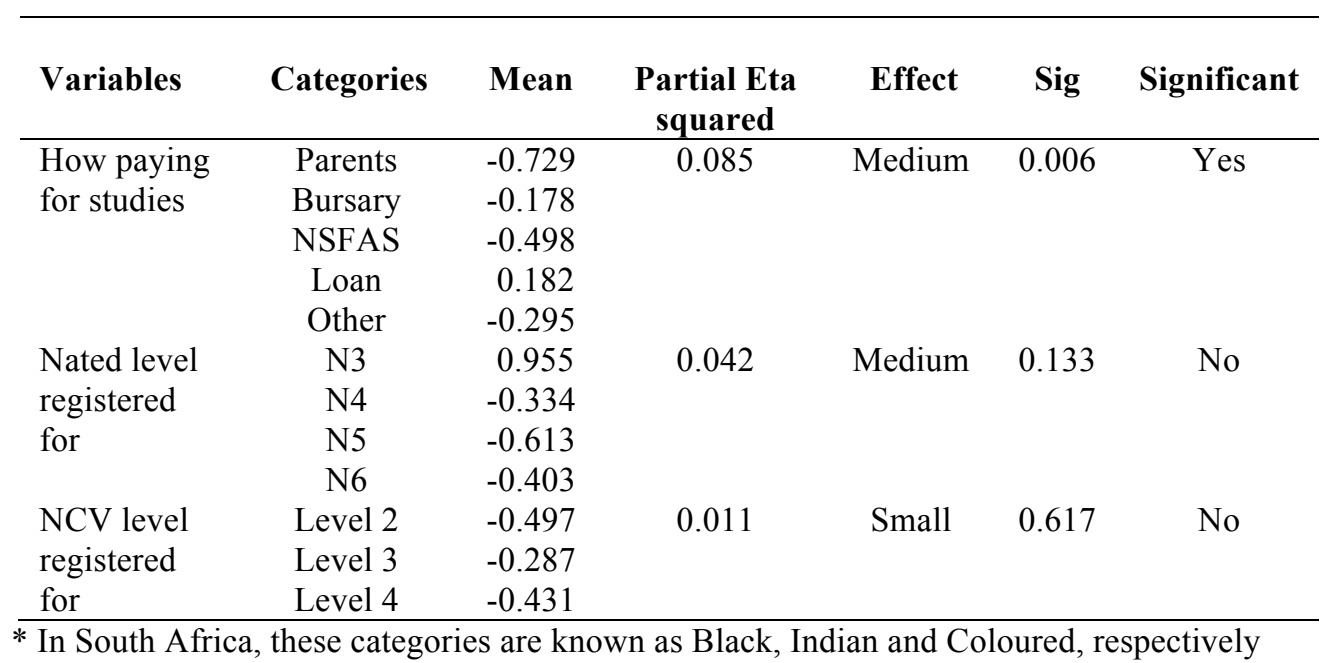

Table 6 shows that, other than "How pay for studies", there were no significant differences in satisfaction with service quality according to the demographic characteristics. Age, ethnicity, gender and $\mathrm{NCv}$ level had small effects and thus are of relatively little interest. Qualification, how paying and Nated level all have a medium effect, probably because, in each case, one response category reflected a positive gap score, whereas the others were all negative. The fact that both Qualification's and Nated's lowest response categories (Grade 9 and N3 respectively) reflected positive gap scores possibly indicates that younger students, with less experience of their college, have not had sufficient opportunities to experience poor service quality, or have not had a chance to be disillusioned about their initial positive attitudes.

Considering the only demographic variable that was statistically significant it is interesting to note that the Loan option had a positive gap score, while Parents had the highest negative gap score. This could be because where students' parents have paid, a higher level of expectation is present, whereas when someone else is paying the students may care less about the service they receive.

\section{DISCUSSION}

The data on expectations, perceptions and gap scores of services quality, which indicate levels of satisfaction with service quality, were analysed in terms of ethnicity, gender, age, highest level at school completed before registering with TVET college, method of tuition fee payment, as well as the Programme/Course and level registered for. The results from the total sample reflected a high level of dissatisfaction, with all expectations exceeding the perceptions of service quality provided. Generally, the results analysed by demographic characteristics differed little from the overall findings, with small effects (partial ETA square close to 0.01 ), specifically ethnicity, gender, age and $\mathrm{NCv}$ level. However, there were a few demographic variables that indicated a medium effect (partial ETA squared of close to 0,06), specifically Qualifications, how paying and Nated level of study. However, only How paying was statistically significant. These individual findings are now explored further, and hypotheses tested in order to come to conclusions about the research objectives. 


\subsection{Gender}

The null hypothesis for Hypothesis 1 states that Gender has no effect on Service Quality Satisfaction. The alternate hypothesis indicates that there is an effect. An inspection of the mean values in Table 6 shows that both gender groups (male and female) have similar negative means. It is noted from Table 6 that the partial eta square $(0.004)$ approximates a small effect that is not statistically significant $(\mathrm{p}=0.422)$. From these findings null hypothesis 1 can be accepted, confirming that no relationship exists between gender and satisfaction with service quality satisfaction.

This finding supports those of Jusoh et al. (2004), Tan and Kek (2004), Koni et al. (2013) and Wilkins and Balakrishnan (2013), which were all conducted in developing nations. They are, however, contradictory to the findings of Joseph et al. (2005), Min and Khoon (2014), Palli and Mamilla (2012), and Zafiropoulos and Vrana (2008), two of which were conducted in developed nations. It may be that gender plays a stronger role in developed than in developing countries.

\section{$5.2 \quad$ Ethnicity}

The null hypothesis for Hypothesis 2 states that Ethnicity has no effect on Service Quality Satisfaction. The alternate hypothesis indicates that there is an effect. An inspection of the mean values in Table 6 shows that the ethnicity groups all have negative means, with Asian (Indian) having the greatest gap scores and Mixed race (Coloured) the smallest. It is noted from Table 6 that the partial eta square (0.012) approximates a small effect that is not statistically significant $(\mathrm{p}=0.361)$. From these findings, null hypothesis 2 can be accepted, confirming that no relationship exists between ethnicity and satisfaction with service quality satisfaction. Although this finding indicates that satisfaction levels do not differ between African (black) and other students, it should be noted that the sample was heavily skewed with 293 African (black) and only 8 students of another ethnicity. We feel though that a finding of little to no difference for this demographic characteristic is probably accurate, but should be treated with caution.

This finding is supported by the only study that included ethnicity (race) as a demographic variable (Jusoh et al., 2004). It is interesting to note that the three studies that included nationality (which could be similar to ethnicity), all found it to be a factor that influences the level of satisfaction (Min \& Khoon, 2014; Tan \& Kek, 2004; Wilkins \& Balakrishnan, 2013). This finding is of course questionable because of the way our sample was skewed towards black students.

\subsection{Age}

The null hypothesis for Hypothesis 3 states that Age has no effect on Service Quality Satisfaction. The alternate hypothesis indicates that there is an effect. An inspection of the mean values in Table 6 shows that the all Age groups have similar negative means, with the older categories having slightly greater gap scores than the two younger categories. However, it is noted from Table 6 that the partial eta square (0.016) approximates a small effect that is not statistically significant $(\mathrm{p}=0.454)$. From these findings, null hypothesis 3 can be accepted, confirming that no relationship exists between Age and satisfaction with service quality satisfaction. 
This finding supports the finding of Min and Khoon (2014) and Palli and Mamilla (2012) but disagrees with Koni et al. (2013). Since our study covered a relatively constrained age grouping (mostly 18 to 23 years old), such similarity of opinions is not unexpected.

\subsection{Qualification prior to registration}

The null hypothesis for Hypothesis 4 states that Qualification before registering has no effect on Service Quality Satisfaction. The alternate hypothesis indicates that there is an effect. An inspection of the mean values in Table 6 shows that the all Qualification groups, except Grade 9, have similar negative means. Grade 9 has a slightly positive gap score, while Grade 12 has the greatest negative score. This may indicate that students with less experience of their college have not had sufficient opportunities to experience poor service quality, or have not had a chance to be disillusioned about their initial positive attitudes, as suggested in section 4.3. Alternatively, those entering with the lowest grade (9) might have been at the TVET college longer, and so their expectations could be less than those who are relatively new in the college (the higher grades). It is noted from Table 6 that the partial eta square (0.05) approximates a medium effect that is not statistically significant $(p=0.079)$. Since the finding is not significant, null hypothesis 4 cannot be rejected, confirming that no relationship exists between Qualification and satisfaction with service quality satisfaction.

No previous studies have included this demographic factor so no comparison with previous literature can be made.

\subsection{Method of paying for tuition fees}

The null hypothesis for Hypothesis 5 states that How paying for studies has no effect on Service Quality Satisfaction. The alternate hypothesis indicates that there is an effect. An inspection of the mean values in Table 6 shows that the all Payment groups, except Loan, have negative means. The Loan option had a positive gap score, while Parents had the highest negative gap score and NSFAS the second highest. Where students' parents have paid, a higher level of expectation of quality service may be present, whereas when someone else is paying, the students may care less about the service they receive. A further reason for the differences could be due to the delays in receiving payment from the NSFAS and bursaryscheme, which causes students to have to continuously enquire from TVET administrative staff whether fees have been paid, and thus perceive a lower level of service.

It is noted from Table 6 that the partial eta square (0.085) approximates a medium effect that is statistically significant $(\mathrm{p}=0.006)$. Since the finding is significant with a medium effect, null hypothesis 5 can be rejected and the alternative accepted, confirming that a relationship does exist between How paying and satisfaction with service quality satisfaction.

Our finding does not support the only other study that considered payment (namely, self-payment or subsidy by the college) as a demographic variable (Palli \& Mamilla, 2012). Since the response categories in the two studies are so different, it is probably not relevant that they came to different conclusions. 
The null hypothesis for Hypothesis 6 states that Nated level registered for has no effect on Service Quality Satisfaction. The alternate hypothesis indicates that there is an effect. An inspection of the mean values in Table 6 shows that the all Nated level groups, except N3, have negative means. N3 students have slightly positive gap scores, while those studying N4 and N5 (in their second or third years at the college) have the greatest negative scores. This may indicate that newer students with less experience of their college have not had sufficient opportunities to experience poor service quality, or have not had a chance to be disillusioned about their initial positive attitudes, as suggested in section 4.3. Furthermore, this may indicate different opinions held by different levels for this cohort. Thus, the length of time at a college could result in different experiences. However, since this qualification is being run out and is to be replaced by the NCv qualification, the service provided for these students might be overlooked, thus resulting in differing perceptions.

It is noted from Table 6 that the partial eta square (0.042) approximates a medium effect that is not statistically significant $(p=0.133)$. Since the finding is not significant null hypothesis 6 cannot be rejected, confirming that no relationship exists between Nated level and satisfaction with service quality satisfaction.

This finding, for the older qualification, supports Jusoh et al. (2004), Koni et al. (2013), Min and Khoon (2014), Wilkins and Balakrishnan (2013), and Zafiropoulos and Vrana (2008). Clearly differing levels of experience influence satisfaction, which may explain why students registered for the older qualification reflect differences according to year level - they have been around longer to experience the poor quality service.

\subsection{NCv Group and level (year) registered for}

The null hypothesis for Hypothesis 7 states that $\mathrm{NCv}$ level registered for has no effect on Service Quality Satisfaction. The alternate hypothesis indicates that there is an effect. An inspection of the mean values in Table 6 shows that the all $\mathrm{NCv}$ level groups have similar negative means, with the middle (level 3 ) category having a slightly smaller gap score than the other two categories. However, it is noted from Table 6 that the partial eta square $(0.011)$ approximates a small effect that is not statistically significant $(\mathrm{p}=0.617)$. From these findings, null hypothesis 7 can be accepted, confirming that no relationship exists between $\mathrm{NCv}$ level and satisfaction with service quality satisfaction.

This finding only supports that of Tan and Kek (2004) - all other studies found some level of influence on satisfaction by different student levels. Since NCv students are relatively new at TVET colleges, maybe they have not had sufficient time to develop a reliable experience of their college's level of service.

\section{CONCLUSIONS AND IMPLICATIONS FOR PRACTICE}

From the above discussion, it can be concluded that the various demographic factors do not have a major influence on TVET students' attitudes and opinions regarding the quality of service they receive from their colleges. Only the method of payment seems to have a medium effect of students' satisfaction with service quality. Clearly most students have high expectations of the service they want to receive and most students feel that they are not 
receiving this desired level of service. In other words, students are receiving a poor level of service and it does not appear as if any particular demographic is being discriminated against in terms of service level. This implies that it is not the nature of the student that is attracting poor quality service, but that poor service appears to be endemic at TVET colleges. It is probably therefore that the poor service quality is due to inadequate systems, inadequate administrative staff training, demotivated staff, or staff with inappropriate attitudes being employed. This further implies that the management of the colleges may be unprofessional and inadequate, as strong and professional educational management should have addressed these issues.

In order to overcome the poor service quality and the probable causes outlined above, it is suggested that each TVET college should institute a formal service quality programme. Such a programme should include, first, an in-depth efficiency study of the systems used and of the staff competencies. Second, performance standards for all aspects of service quality should be set. These standards should include the five service quality dimensions, namely tangibles, reliability, responsiveness, assurance and empathy and should specify the level of service required of a 'good quality service'. Third, all college management should undergo training in professional management skills to ensure competent leadership of their colleges so as to provide excellent service. Fourth, all administrative staff should undergo training in customer service to improve the service provided and to improve the attitudes with which students are dealt. Such training should also cover all five of the service quality dimensions. Fifth, regular monitoring and evaluation studies should be conducted to assess if improvements have been made, and to ensure that such improvements are maintained. Such regular (at least monthly) monitoring should be of the five service quality dimensions so that management, and the front-line staff, can be kept aware of the service quality that they are providing. Such regular measurements would also highlight where improvements are needed.

\section{LIMITATIONS}

As with most social science research, this study also had certain limitations. Only six TVET colleges in only one province participated - therefore the findings may not be representative of all TVET colleges in South Africa. But with the large proportion of KZN colleges in the sample, we are confident that the findings are, in fact, representative of the KZN province. The participating colleges covered urban and rural areas and a range of respondents (e.g. new and old curricula; campuses with larger and smaller numbers of students). Since the interviewed sample was selected via convenience sampling, the results could be biased towards respondents who are more outgoing, or who may have stronger negative attitudes and so are more likely to want to participate. Possible solutions to this in future are to use some form of random sampling, or to conduct a census through questionnaire completion in classrooms. A further limitation was that the sample was heavily skewed towards African (black) students, although this is probably representative of the KwaZulu-Natal TVET student population.

\section{FUTURE RESEARCH}

Similar research should be repeated regularly in the KZN province as student demographics change, as do students' expectations and perceptions. TVET colleges in other South African provinces should also be researched in order to identify if the results are generalizable to the rest of South Africa. Such research should try to obtain a sample that is more representative 
of the South African population, with more white, mixed race (coloured) and Asian (Indian) respondents. Qualitative research would also be valuable in order to gain a more in-depth knowledge and understanding of students' feelings. Other demographic factors (e.g. part/full time, students with disabilities, language, household income, etc.) and other types of colleges (e.g. private colleges) could also be investigated to better understand the factors that influence satisfaction with service quality. In order to better understand the causes and possible solutions to service quality problems, research with TVET college employees (academic and administrative) would be worthwhile.

\section{References}

Akoojee, S., \& McGrath, S. (2008). The marketing of public FET colleges in South Africa. Issues for Policy and Practice, 45(5), 130-154.

Akoojee, S. (2009). Scarce skill and public technical and vocational education and training (TVET) in South Africa: Twin challenges or two sides of the same coin? Southern Review of Education, 15(2), 117-138.

Athiyaman, A. (1997). Linking student satisfaction and service quality perceptions: the case of university education. European Journal of Marketing, 31(7), 528-540.

Binsardi, A., \& Ekwulungo, F. (2003). International marketing of British education: Research on student perceptions and UK market penetration. Marketing Intelligence and Planning, 21(5), 318-327.

Bruhn, M., \& Georgie, D. (2006). Service marketing: Managing the service value chain. London: Prentice-Hall, Pearson.

Çerri, S. (2012). Assessing the quality of higher education services using a modified Servqual scale. Annales Universitatis Apulensis Series Oeconomica, 14(2), 664-679

Ceza, N. (2008). Student academic support as an intervention strategy to improve student performance. South African College Principals Organisation. Walter Sisulu University, South Africa. 1-6.

Corbishley, K.M., \& Mason, R.B. (2011). Cause-related marketing and consumer behaviour in the greater eThekweni area. African Journal of Business Management, 5(17), 7232-7239.

Cosser, M. (2011). Pathway through the education and training system: Do we need a new model? Journal of Perspective Education, 29(2), 70-79.

de Jager, J.W., \& du Plooy, A.T. (2006). Student expectations of service quality in tertiary education: A comparison between prospective and current students. Acta Commercii, 6(1), 10-19

Draper, S. (2018). Effect size. Available at http://www.psy.gla.ac.uk/ steve/best/effect.html

Harris, E.K. (2003). Customer service: A practical approach (3rd ed.), Upper Saddle River, NJ: Prentice-Hall.

Hasan, H.F.A., Ilias, A., Rahman, R.A., \& Razak, M.Z.A. (2008). Service quality and student satisfaction: A case study at private higher education institutions. International Business Research, 1(3), 163-175

Introduction to SAS. (2007). UCLA: Academic Technology Services, Statistical Consulting Group. Available at: http://www.ats.ucla.edu/stat/sas/notes2/

Ivy, J. (2001). Higher education institution image: A correspondence analysis approach. The International Journal of Educational Management, 15(6/7), 276-282.

Joseph, M., Yakhou, M., \& Stone, G. (2005). An educational institution's quest for service quality: customers' perspective. Quality Assurance in Education, 13(1), 66-82

Jusoh, A., Omain, S.Z., Majid, N.A., Som, H.M., \& Shamsuddin, A.S. (2004). Service quality in higher education: Management students' perspective. Research VOT No. 71982 Research Management Centre, University of Technology Malaysia

Koni, A., Zainal, K., \& Ibrahim, M. (2013). An assessment of the services quality of Palestine higher education. International Education Studies, 6(2), 33-48.

Leedy, P.D., \& Ormrod, J.E. (2005). Practical research: Planning and design (8th ed.). Upper Saddle River, NJ: Merrill Prentice-Hall.

Lotz, C. (2009). Customer service quality at selected commercial health and fitness centres in KwaZulu-Natal. (Master of Technology: Marketing dissertation). Durban University of Technology, Durban, South Africa.

Maringe, F., \& Foskett, N.H. (2002). Marketing university education: the Southern African experience. Higher Education Review, 34(3), 35-51.

Min, S., \& Khoon, C.C. (2014). Demographic factors in the evaluation of service quality in higher education: A Structural Equation Model (SEM) approach. International Journal of Marketing Studies, 6(1), 90-102

Mmako, M., \& Schultz, C. (2016). An employee engagement framework for technical vocational education and training colleges in South Africa. South African Journal of Higher Education 30(2), 143-163

Myeza, J., Mason, R.B., \& Peddermors, V. (2010). Economic and social implications of the sardine run on local indigenous communities. African Journal of Marine Science, 32(2), 399-404. 
Nadiria, H., Kandampully, J., \& Hussain, K. (2009). Students' perceptions of service quality in higher education. Total Quality Management, 20(5), 523-535

Palli, J.G., \& Mamilla, R. (2012). Students' opinions of service quality in the field of higher education. Creative Education, 3(4), 430-438

Pérez, M.S., Abad, J.C., \& Fernandeź, R.S. (2007). Effects of service quality dimensions of behavioural purchases: A study in public-sector transport. Managing Service Quality, 17(2), 134-154

Pillay, M., Mbambo, S.N., \& Mason R.B. (2017). Service quality's role in students' decisions to study at further education and training colleges. International Journal of Educational Science, 18(1-3), 87-100.

Pillay, P. (2010). Linking higher education and economic development: implications for Africa from three successful systems. Centre for Higher Education Transformation (CHET), Wynberg, South Africa.

Russell, M. (2005). Marketing Education. A review of service quality perception among international students. International Journal of Contemporary Hospitality Management, 17(1), 65-77.

South Africa. Department of Education. (2007). Education statistics in South Africa at a glance 2006. Pretoria: Government Printer.

South Africa. Department of Education. (2008). Education Statistics in South Africa at a glance 2007. Pretoria: Government Printer.

Tan, K.C., \& Kek, S.W. (2004). Service quality in higher education using an enhanced SERVQUAL approach. Quality in Higher Education, 10(1), 17-25

Tsinidou, M., Gerogiannis, V., \& Fitsilis, P. (2010). Evaluation of the factors that determine quality in higher education: An empirical study. Quality Assurance in Education, 18(3), 227-244

TVET Colleges South Africa. (2016). Public TVET colleges. Available at: http://www.fetcolleges.co.za/Site_Public_FET.aspx

Van Rensburg, D. (2016). Blade's college conundrum. Fin 24/City Press. Available at: http://www.fin24.com/Economy/blades-college-conundrum-20161028

Wael, T. (2015). Using Servqual model to assess service quality and students satisfaction in Pavia University Italy. International Journal of Research in Business Studies and Management, 2(3), 24-31.

Wilkins, S., \& Balakrishnan, M.S. (2013). Assessing student satisfaction in transnational higher education. International Journal of Educational Management, 27(2), 143-156.

Yu, G., \& Lee, D-J. (2008). A model of quality of college life (QCL) of students in Korea. Social Indicators Research, 87(2), 269-285.

Zafiropoulos C., \& Vrana, V. (2008). Service quality assessment in a Greek higher education institute. Journal of Business Economics and Management, 9(1), 33-45

Zeithaml, V.A., Bitner, M.J., \& Gremler, D.D. (2006). Service marketing: Integrating customer focus across the firm (4th ed.), New York: McGraw-Hill. 